\title{
In Vitro Effect of Degradation in Sacco in the Rumen on the Anthelmintic Properties of Parkia Biglobosa and Pterocarpus Erinaceus on Haemonchus Contortus
}

\section{Vidjinnangni Fifamè Grâce Nadège Dèdéhou (PhD)}

Laboratoire d'Ethnopharmacologie et de Santé Animale, Faculté des Sciences Agronomiques, Université d'Abomey Calavi, Cotonou, Bénin. Laboratoire d'Ecologie, de Santé et de Production Animale, Faculté d'Agronomie, Université de Parakou, Parakou, Bénin Sévérin Babatoundé (PhD, Full Professor)

Laboratoire de Zootechnie, Université d'Abomey Calavi, Cotonou, Bénin.

\section{Mahulé Sylvie Hounzangbé-Adoté (PhD, Full Professor)}

Laboratoire d'Ethnopharmacologie et de Santé Animale, Faculté des Sciences Agronomiques, Université d'Abomey Calavi, Cotonou, Bénin.

Doi: 10.19044/esj.2018.v14n21p87 URL:http://dx.doi.org/10.19044/esj.2018.v14n21p87

\begin{abstract}
Parkia biglobosa and Pterocarpus erinaceus are traditionally used to treat various ailments including helminth infections. This study was undertaken to evaluate the effect of the rumen degradability on anthelmintic properties of the two plants and to examine the possible role of tannins and/or polyphenols on these properties. Hydro-acetone extracts of in sacco degradability residues of $P$. biglobosa pods and $P$. erinaceus leaves were screened in vitro to determine the possible anti-parasitic effects against eggs and infective larvae of Haemonchus contortus. In addition, the possible involvement of tannins and/or polyphenols was examined by comparing the levels of inhibition of larval migration obtained with the same extracts, after of not addition of PVPP. Extracts of both plants induced significant egg hatch inhibition $(\mathrm{p}<0.001)$. The effects were dose and incubation period dependent. Extracts of both plants have shown again remarkable larval migration inhibition compared to the PBS ( $<<0.05)$. The effect of incubation period was not significant $(\mathrm{p}>0.05)$. These results suggest that the plants did not lose their anthelmintic properties after rumen degradation. The use of the PVPP indicated for almost all of the extracts that tannins and/or polyphenols are largely involved in the effect. Complementary investigations are necessary to understand the metabolism of these plants in the digestive tract of the animals.
\end{abstract}


Keywords: Parkia biglobosa, Pterocarpus erinaceus, rumen degradation, anthelmintic, Haemonchus contortus.

\section{Introduction}

Gastrointestinal nematode parasitism, especially Haemonchus contortus constitutes one of the most serious constraints affecting ruminant production in developing countries such as Benin (Attindehou et al., 2012). It has an impact on production which results in economic losses. Parasitic nematodes cause mortality, severe weight losses, low milk output and reproductive failure in livestock (Alawa et al., 2002; Bizimenyera et al., 2008). The control of gastrointestinal nematodes predominantly depends upon chemotherapy. However, development of drug resistance in the parasites (Kaplan, 2004), effect of drug residues on human and high costs of the synthetic drugs have led in search for the treatment and/or control of parasites (Brunet, 2008; Olounladé et al., 2011).

Although alternatives such as grazing management, selective breeding for resistant hosts, worm vaccines and the use of biological agents have been proposed, their adoption and success under conditions that exist in most developing countries has not been satisfactory, because of factors such as finance, technical know-how (Krecek and Waller, 2006). In recent years, there has been a resurgence of interest in traditional health care practices and the use of plants with anthelmintic properties which can reduce or control parasitic nematode infestations is one of the alternative sustainable approaches.

Parkia biglobosa and Pterocarpus erinaceus are important multipurpose trees and are well known in many African countries. They provide building materials, wood, food, fodder and other commodities and are especially important as traditional medicines (Zerbo et al., 2011; Tchacondo et al., 2011). They showed in previous study anti-parasitic activity against $H$. contortus (Dèdéhou et al., 2014).

The aim of this study is to evaluate the effect of the rumen degradability on anthelmintic activity of $P$. biglobosa and $P$. erinaceus against eggs and infective larvae of $H$. contortus.

\section{Material And Methods Plants Collection}

The plant materials were the leaves of $P$. erinaceus and the pods of $P$. biglobosa. The plants were collected from their natural habitats in the center part of Benin. Samples of $P$. erinaceus and $P$. biglobosa were identified by plant taxonomist at the National Herbarium of Benin under numbers 
AA6368/HNB and AA6385/HNB respectively. Plant parts were air dried at room temperature, ground and kept in bottle until processed.

\section{Animals and diets}

Five African Dwarf sheep (average weight: $30 \mathrm{~kg}$ ) were used for the in sacco experiments. Each sheep was fitted with a rumen cannula $(40 \mathrm{~mm})$ and penned individually. Each sheep received a daily ration containing 35 $\mathrm{g} / \mathrm{kg}$ of body weight (BW) of Panicum maximum var. C1, $7.5 \mathrm{~g} / \mathrm{kg} \mathrm{BW}$ of cotton seeds and $7.5 \mathrm{~g} / \mathrm{kg} \mathrm{BW}$ of peelings of cassava (Manihot esculenta). The diet was given in two equal portions at 8 hour intervals. Water and a mineral lick were always available.

\section{In sacco study and plants residues extraction}

The nylon bag method was used for plant powders degradability in sheep rumens. The heat-sealed bags, measuring $10 \times 15 \mathrm{~cm}$, were made of nylon cloth having a calibrated pore size of either $40 \mu \mathrm{m}$. Approximately $5 \mathrm{~g}$ of powder of $P$. erinaceus leaves or $P$. biglobosa pods, ground through a 2 $\mathrm{mm}$ sieve, were put into each bag. Three bags were fixed on a plastic pipe 30 $\mathrm{cm}$ long connected to the plug of the rumen cannula. The bags were introduced into the rumen just before the morning feeding and incubated for 24, 48, and 72 hours. Three repetitions were carried out on each sheep. Thus 45 nylon bags were incubated for each powder.

At the end of incubation, the bags were removed from the rumen and manually washed at least three times in cold water under a water jet of tap. They were then squeezed gently by hand and dried at $40{ }^{\circ} \mathrm{C}$ for 48 hours. The dried bags were weighed to determine the amount of residual dry matter. The residue was ground and preserved for the extraction.

After in sacco degradation, hydro-acetone extraction was performed by soaking $10 \mathrm{~g}$ of dried and ground residues in $100 \mathrm{ml}$ of $70 \%$ acetone for 1 $\mathrm{h}$ at $40{ }^{\circ} \mathrm{C}$. After filtration, the solvent was evaporated using a Rota vapor and dried at $40{ }^{\circ} \mathrm{C}$. The extract was kept in a sample at $4{ }^{\circ} \mathrm{C}$ until used for the assays.

\section{Egg hatch assay}

Eggs used in the assay were freshly collected from feaces of a donor sheep experimentally infected with Haemonchus contortus. The egg hatch assay was conducted according to World Association for the Advancement of Veterinary Parasitology (WAAVP) guidelines (Coles et al., 1992). The eggs were extracted, repeatedly washed and distributed in 96-multi-well plates at a density of 100 eggs per well. Increasing concentrations of plant extracts $(75,150,300,600,1200$ and $2400 \mu \mathrm{g}$ dry matter (DM) per ml were obtained from dry ground extracts dissolved in phosphate buffered saline 
(PBS 0.15 M, pH = 7) and then added to each well. Each concentration was tested on six replicates. In addition, a positive (thiabendazole at 125, 250 and $500 \mu \mathrm{g} / \mathrm{ml}$ and negative control were included in the assay. Eggs were incubated for $48 \mathrm{~h}$ at $24{ }^{\circ} \mathrm{C}$. Thereafter, the number of larvae present per well was counted and the percentage hatched determined as the ratio between the number of larvae to the number of eggs deposited per well. A mean percentage of hatching was calculated for each concentration of the different plant extracts.

\section{Larval migration inhibition assay}

This test is aimed at evaluating the anthelmintic effect of the plant extracts on the migration capacity of the $\mathrm{L}_{3}$ s larvae. This test was performed according to Rabel et al. (1994). H. contortus $\mathrm{L}_{3} \mathrm{~s}$ were obtained by fecal culture. Eggs reached the $\mathrm{L}_{3}$ s stage after 10 days. The $\mathrm{L}_{3}$ s were then collected using Baermann's devices. The anthelmintic effect of each extracts was tested using 150, 300, 600, $1200 \mu \mathrm{g} / \mathrm{ml}$ concentrations. Negative (PBS) and positive controls (levamisole at 125, 250 and $500 \mu \mathrm{g} / \mathrm{ml}$ ) were also prepared in PBS and incorporated to the assay. Three replicates were run for each extract and for the controls. After $3 \mathrm{~h}$ of incubation at room temperature $\left(25^{\circ} \mathrm{C}\right)$, the larval suspensions were rinsed out 3 times with PBS buffer. After the final washing, $1 \mathrm{ml}$ of larvae at the concentration of $1000 \mathrm{~L}_{3} \mathrm{~s} / \mathrm{ml}$ was added to inserts equipped with a $20 \mu \mathrm{m}$ mesh. Sieves were then placed in a conical tube, with the mesh just above the PBS. After $3 \mathrm{~h}$ of incubation, the inserts were removed and the number of larvae which had actively migrated though the mesh was determined.

The percentage of LMI was calculated as

$$
L M I=\frac{T-M}{T} x 100
$$

where $\mathrm{T}$ is the total number of $\mathrm{L}_{3}$ s deposited in the sieve and $\mathrm{M}$ the number of $\mathrm{L}_{3} \mathrm{~S}$ present in the PBS.

Polyvinyl polypyrrolidone (PVPP) is used to show the involvement of tannins on larval migration. PVPP forms complexes with tannins and polyphenols and thus blocks their potential biological activity (Makkar, 2003). PVPP was added to the 2 plant extracts at a concentration of $1200 \mu \mathrm{g} / \mathrm{ml}$ for 2 hours in a 1:50 ratio (Barrau et al., 2005). These solutions were then centrifuged at $4500 \mathrm{RPM}(5 \mathrm{~min}, 20 \circ \mathrm{C})$. After centrifugation, the supernatant and the extracts without adding PVPP were used to incubate infective larvae of $H$. contortus. Thereafter, the larval migration inhibition assay was performed according to the procedure described previously. 


\section{Statistical analysis of results}

The mean values were calculated and the increasing effect of the concentration of plant extracts was performed using GLM process through the package MASS of free software (Venables and Ripley, 2002). The hierarchical organization of mean was made using Multiple Comparison Test of Tukey through HSD test procedure of the package agricolae (De Mendiburu, 2013) of free software R (R Core Team, 2013).

\section{Results}

\section{Dry matter disappearance in the rumen}

$P$. biglobosa and $P$. erinaceus dry matter disappearance percentages according to the incubation period are presented in Figure 1. The matter loss observed for $P$. biglobosa was greater than of $P$. erinaceus. After 72 hours of incubation the matter loss was $33.3 \%$ for P. biglobosa and $16.7 \%$ for $P$. erinaceus. The disappearance of the dry matter was almost linear for the two plants. Two kinetic times namely 24 and 72 hours were appointed for the biological tests on the parasites and their effects were compared with 0 hour of incubation.

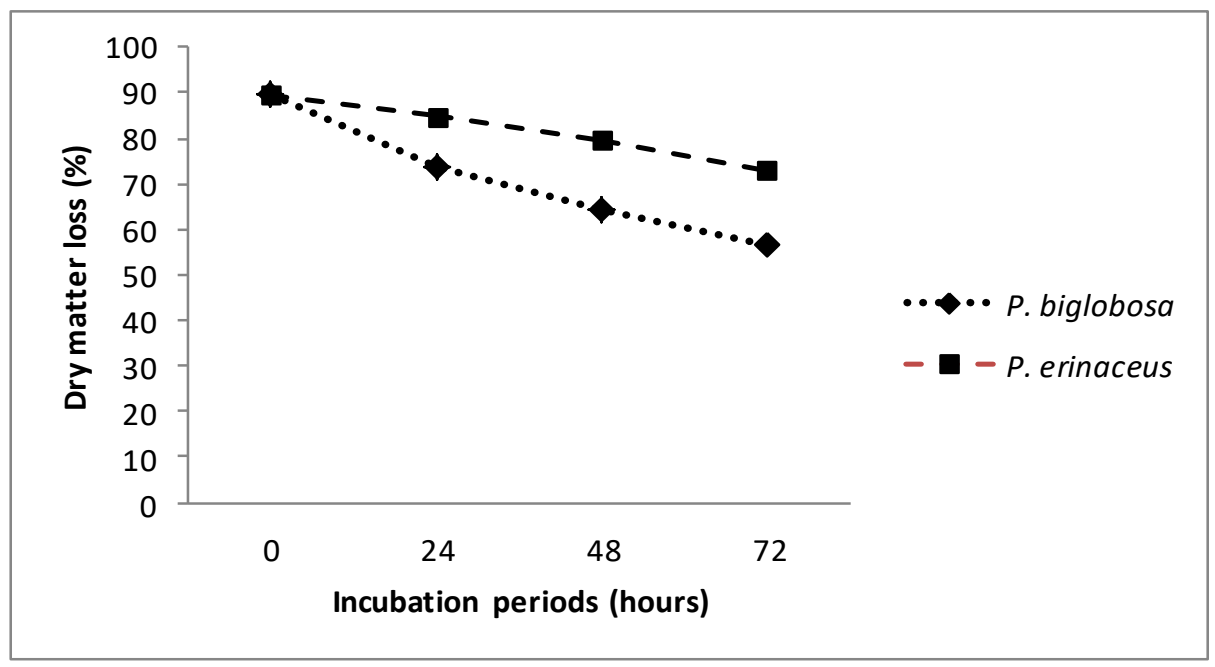

Figure 1: Parkia biglobosa and Pterocarpus erinaceus dry matter degradation in the rumen.

\section{Effect on egg hatching}

The extracts of residues of $P$. biglobosa pods and $P$. erinaceus leaves showed significant effect on egg hatching compared to the negative control ( $\mathrm{p}$ $<0.001$ ). The mean hatching rate measured in the negative control was $88 \%$. With the positive control (Thiabendazole) concentrations used, more than $99 \%$ of eggs incubated did not hatch. The effect of highest concentration of extract $(2400 \mu \mathrm{g} / \mathrm{ml})$ was similar to positive control (Thiabendazole) $(\mathrm{p}<0.05)$. The 
mean eggs hatching values obtained increased significantly $(\mathrm{P}<0.05)$ with the decrease of the concentrations of the extracts (Figure 2). The ovicidal activity observed is dose and incubation period-dependent ( $\mathrm{p}<0.001)$. Both plants showed the same activity on eggs $(\mathrm{p}<0.05)$.



Figure 2: Dose-dependent profile of the percent hatching egg of $H$. contortus at concentrations $(75-2400 \mu \mathrm{g} / \mathrm{ml})$ of plant residues extracts.

\section{Effects on larval migration}

The mean percent values of the migration of $H$. contortus infective larvae exposed to different concentrations of $P$. biglobosa and $P$. erinaceus extracts are presented in Figure 3. The mean migration rate observed for the larvae of negative control was $97 \%$. The extracts exhibited larval migration inhibition at all concentrations tested compared to negative control (PBS) (p $<0.05$ ) but less than positive control (levamisole) $(\mathrm{p}<0.05)$. The mean migration rate observed for the larvae of extracts was less than $47 \%$. The effect of incubation period was not significant ( $p>0.05)$. Addition of PVPP to the extracts decreased very partially the inhibiting activity of $P$. biglobosa at 0 hour of incubation. For the other extracts, the addition of PVPP induced a larval migration restoration. The percentage of migration was doubled or tripled compared to the extracts untreated with PVPP (Figure 4). 


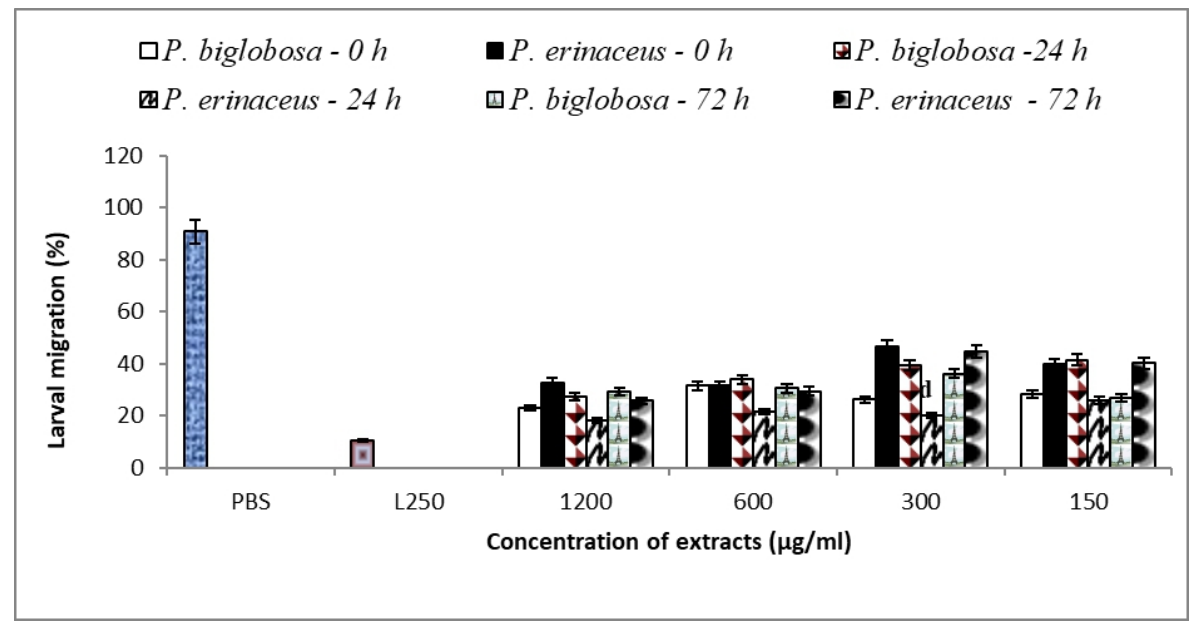

Figure 3: Variation of the rate of larval migration of $H$. contortus with PBS, levamisole and plant residues extracts at concentrations $(150-1200 \mu \mathrm{g} / \mathrm{ml})$.

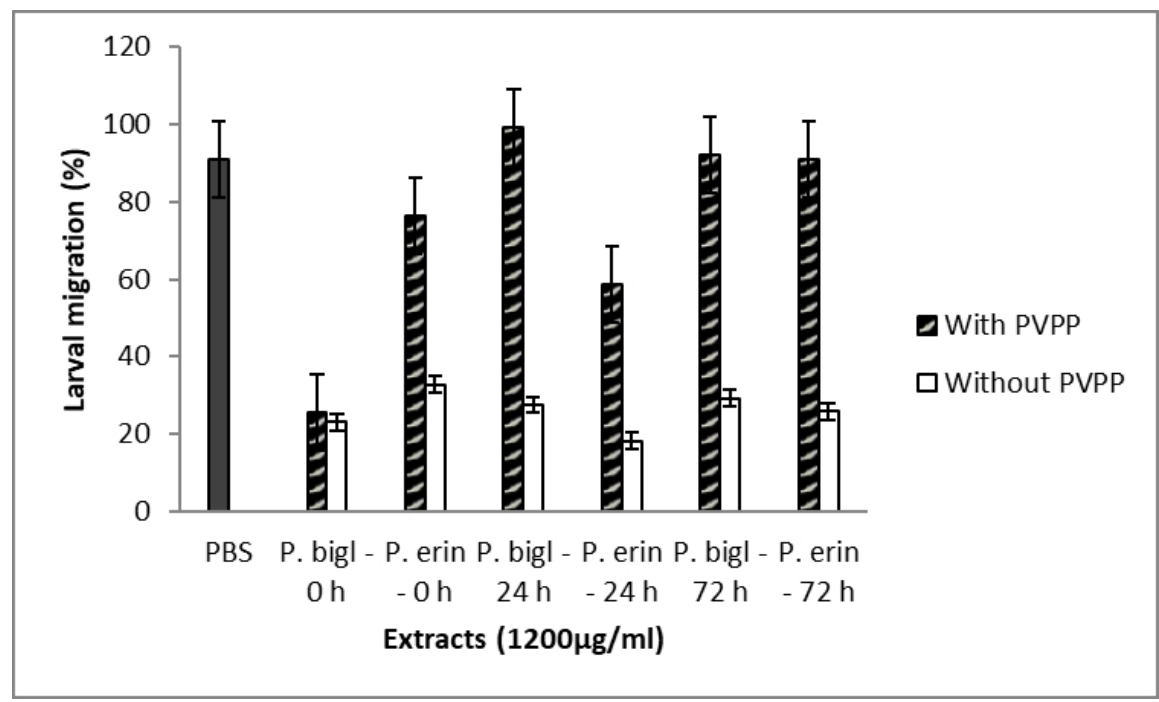

Figure 4: Variation of the effect of the extracts of Parkia biglobosa (P. bigl) and Pterocarpus erinaceus (P. erin) in presence (With) or not (Without) of the PVPP on the larval migration of Haemonchus contortus.

\section{Discussion}

Acetone was the solvent of extraction used in this study. This solvent was selected because of the greatest effectiveness of the hydro-acetone extracts of Parkia biglobosa and Pterocarpus erinaceus brought back by previous studies (Dèdéhou et al., 2014). These extracts gave in vitro the best results on the larvae and the adult worms of $H$. contortus compared with the hydro-methanol extracts (Dèdéhou et al., 2014). 
The extracts of $P$. biglobosa and $P$. erinaceus inhibited dosedependent egg hatching and larval migration of $H$. contortus. The results obtained for egg hatching are comparable with those reported by other authors with Senna occidentalis, Leonotis ocymifolia, Leucas martinicensis, Rumex abyssinicus, Albizia schimperiana, Maesa lanceolata and Plectranthus punctatus (Tadesse et al., 2009; Eguale et al., 2011). These results are better than those reported by Nwosu et al. (2006) with Azadirachta indica. For larval migration inhibition, the results obtained confirm those previously announced by Dèdéhou et al. (2014). Also, Soetan et al. (2011) reported the anthelmintic effect of extracts of seeds and leaves of P. biglobosa on bovine nematode eggs. Phytochimical screening of the hydro-acetone extracts of $P$. biglobosa and $P$. erinaceus revealed for two plants the presence of several bioactive molecules like tannins, triterpenes, flavonoids, saponins and alkaloids (Dèdéhou et al., 2014). The role of some of these molecules was suspected or shown in the anthelmintic effects of both plants (Ayers et al., 2008; Brunet, 2008; Olounladé et al., 2011). Molan et al. (2003) and Brunet (2008) showed that flavonoids induced structural deteriorations on infective larvae thus preventing their migration. According to Maciel et al. (2006) and MarieMagdeleine et al. (2009), the development of the larvae could be inhibited by terpenoids. Eguale et al. (2007) and Marie-Magdeleine et al. (2009) suspected the role of saponins in egg hatch inhibition.

The two plants did not lose their anthelmintic effects after 24 to 72 hours' incubation in the rumen. After 72 hours' incubation, the larval migration inhibition activity of the two plants was preserved and their egg hatch inhibition activity was increased. This could be related to a greater concentration in bioactive substances of the residues resulting from the matter loss of the powders incubated during digestion in the rumen. These results are similar to those found by Alowanou et al. (2015) with Mitragyna inermis, Combretum glutinosum et Bridelia ferruginea and those of Minaflinou Sacca Sidi et al. (2017) with Newbouldia laevis, where plants kept their anthelmintic properties after incubation in the rumen of sheep. On the over hand, with Zanthoxylum zanthoxyloides a reduction in anthelmintic activity was observed after incubation in the rumen (Minaflinou Sacca Sidi et al., 2017).

Many hypotheses were emitted as for the implication of certain bioactive molecules in the anthelmintic effects of the plants. However, few studies were interested in becoming of these molecules in the digestive tract of the animals. Hydrolysable tannins are hydrolyzed by bacteria in the rumen causing the release of the gallic acids and can be further metabolized to other compounds such as pyrogallol (Singh et al., 2001; Min et al., 2003). The breakdown products are then absorbed and circulate in blood. This can reduce the availability of the secondary metabolites of the plants and consequently their therapeutic effectiveness. Condensed tannins have the properties to form 
complexes with macromolecules, including proteins, especially prolinerich proteins (Waterman, 1999). The degree of complexation of tannins with proteins depends on the molecular mass, structure and the configuration of both substances (Mueller-Harvey, 2006; Poncet-Legrand et al. 2006). These interactions are usually due to hydrogen bonds and/or hydrophobic interactions (Poncet-Legrand et al. 2006). In the acidic conditions of the abomasum, condensed tannins are released and are thus available in portions of digestive tract which follows upon the rumen. This would justify the aptitude of the plants which contain these tannins to disturb the viability of the worms or the fertility of the females (Azando et al., 2011). The effect of degradation in the rumen on terpenes would vary according to the nature of terpene. Malecky et al. (2009) after using in vitro incubation of seventeen terpenes with mixed rumen bacteria from dairy goats obtained recovery rates different markedly among terpenes, partly in relation to the presence of oxygen and rings in the molecules. Mathison et al. (1999) indicated that alfalfa (Medicago sativa) saponins were rapidly released into rumen fluid and extensively degraded in the digestive tract of sheep but no attempt was made to determine how closely the products of degradation were related to the original molecules.

Our second objective was to obtain indications on the nature of the active compounds responsible for the anthelmintic activity of $P$. biglobosa and $P$. erinaceus. In particular, we tested the hypothesis that tannins and/or polyphenols were involved in this activity by comparing the effects of the same extracts with or without addition of PVPP which is known to create complexes with polyphenols in particular tannins (Makkar, 2003). The use of the PVPP induced for almost all of the extracts an increase in the larval migration as in the PBS. This indicates that the tannins and/or polyphenols are mainly responsible for the inhibiting activity observed. However, the similar effects exerted by the extracts of $P$. biglobosa at 0 hour treated or not with PVPP indicates the presence of nonphenolic substances which are implied in the action of this plant. The results obtained with 24 and 72 hours would indicate a degradation of these substances in the rumen.

\section{Conclusion}

The present study has shown that extracts of $P$. biglobosa and $P$. erinaceus have some anthelmintic activities against egg and larvae of Haemonchus contortus. The two plants preserved their anthelmintic properties after incubation in sacco in the rumen. Incubation during 72 hours in the rumen increased the action of the two plants on eggs.

Taking into consideration these results, it would be interesting in later studies to proportion the main bioactive molecules of these plants in different parts of digestive tract of sheep to know which molecules act on the parasites. 


\section{Acknowledgements}

Authors thank the Ministry of Higher Education and Scientific Research in Republic of Benin and the project "Valorisation des Plantes locales pour l'Amélioration de la santé et de la Production des animaux d'élevage (VPMAP)" in West Africa financed by UEMOA through PAES Project for their financial support to this study.

\section{References:}

1. Alawa, C.B.I., Gefu, J.O., Abdu, P.A., Chiezey, N.P., Adeyinka, I.A. \& Mohammed, A.K. (2002). Incidence of parasites in cattle sold around Zaria. Journal of Agriculture and Environment, 3: 195-198.

2. Alowanou, G.G.,Olounladé, A.P., Koudandé,O.D., Babatoundé, S., Hounzangbé-Adoté M.S. (2015). Effets de la digestion dans le rumen sur les propriétés anthelminthiques de Bridelia ferruginea (Benth.), Mitragyna inermis (Willd.) Kuntze et Combretum glutinosum (Perr. Ex DC.). Revue CAMES (Science de la vie, de la terre et agronomie), 03(2) : $50-56$.

3. Attindehou, S., Salifou, S., Biaou, C.F., Bassa Gbati, O., AdamouN'diaye, M. \& Pangui, L.J. (2012). Epidemiology of haemonchosis in sheep and goats in Benin. Journal of Parasitology and Vector Biology, 4: $20-24$.

4. Ayers, S., Zink, D.L., Mohn, K., Powell, J.S., Brown, C.M., Murphy, T., Brand, R., Pretorius, S., Stevenson, D., Thompson, D. \& Singh, S.B. (2008). Flavones from Struthiola argentea with anthelmintic activity in vitro. Phytochemistry, 69: 541-545.

5. Azando, E.V.B., Olounladé, A.P., Hounzangbé-Adoté, M.S. \& Hoste, H. (2011). Effets anthelminthiques in vivo de la poudre de feuilles de Zanthoxylum zanthoxylö̈des et de Newbouldia laevis sur les nématodes parasites gastro-intestinaux des chevreaux Djallonké. International Journal of Biological and Chemical Sciences, 5: 10541062.

6. Barrau, E., Fabre, N., Fouraste, I. \& Hoste, H. (2005). Effect of bioactive compounds from sainfoin (Onobrychis viciifolia Scop.) on the in vitro larval migration of Haemonchus contortus : role of tannins and flavonol glycosides. Parasitology, 131: 531-538.

7. Bizimenyera, E.S., Meyer, S., Naidoo, V., Eloff, J.N. \& Swan, G.E. (2008). Efficacy of Peltophorum africanum Sond. (Fabaceae) extracts on Haemonchus contortus and Trichostrongylus colubriformis in sheep. Journal of Animal and Veterinary Advances, 7: 364-371.

8. Brunet, S. (2008). Analyse des mécanismes d'action antiparasitaire de plantes riches en substances polyphénoliques sur les nématodes du 
tube digestifs des ruminants. PhD thesis, Paul Sabatier University, Toulouse, pp 246.

9. Coles, G.C., Bauer, C., Borgsteede, F., Geerts, S., Klei, T.R., Taylor, M.A. \& Waller, P.J. (1992). World association for advancement in veterinary parasitology (WAAVP) methods for the detection of anthelmintic resistance in nematodes of veterinary importance. Veterinary Parasitology, 44: 35-43.

10. De Mendiburu, F. (2013). Agricolae: Statistical Procedures for Agricultural Research, R package version 1. 1-4. http://CRAN.Rproject.org/package=agricolae

11. Dèdéhou, V.F.G.N., Olounladé, P.A., Adenilé, A.D., Azando, E.V.B., Alowanou, G.G., Daga, F.D. \& Hounzangbé-Adoté, M.S. (2014). Effets in vitro des feuilles de Pterocarpus erinaceus et des cosses de fruits de Parkia biglobosa sur deux stades du cycle de développement de Haemonchus contortus nématode parasite gastro-intestinal de petits ruminants. Journal of Animal and Plant Sciences 22: 3368-3378.

12. Eguale, T., Tadesse, D. \& Giday, M. (2011). In vitro anthelmintic activity of crude extracts of five medicinal plants against egg-hatching and larval development of Haemonchus contortus. Journal of Ethnopharmacology, 137: 108-113.

13. Eguale, T., Tilahun, G., Debella, A., Feleke, A. \& Makonnen, E. (2007). Haemonchus contortus: in vitro and in vivo anthelmintic activity of aqueous and hydro-alcoholic extracts of Hedera helix. Experimental Parasitology, 116: 340-345.

14. Kaplan, R.M. (2004). Drug resistance in nematodes of veterinary importance: a status report. Trends in Parasitology, 20: 477-481.

15. Krecek, R.C. \& Waller, P.J. (2006). Towards the implementation of the "basket of options" approach to helminth parasite control of livestock: Emphasis on the tropics/subtropics. Veterinary Parasitology, 139: 270-282.

16. Maciel, M.V., Morais, S.M., Bevilaqua, C.M.L., CamurcaVasconcelos, A.L.F., Costa, C.T.C. \& Castro, C.M.S. (2006). Ovicidal and larvicidal activity of Melia azedarach extracts on Haemonchus contortus. Veterinary Parasitology, 140: 98-104.

17. Makkar, H.P.S. (2003). Effects and fate of tannins in ruminant animals, adaptation to tannins, and strategies to overcome detrimental effects of feeding tannin-rich feeds. Small Ruminant Research, 49: 241-256.

18. Marie-Magdeleine, C., Hoste, H., Mahieu, M., Varo, H. \& Archimede, H. (2009). In vitro effects of Cucurbita moschata seed extracts on Haemonchus contortus. Veterinary Parasitology, 161: 99-105.

19. Mathison, G.W., Soofi-Siawash, R., Klita, P.T., Okine, E.K. \& Sedgwick, G. (1999). Degradability of alfalfa saponins in the digestive 
tract of sheep and their rate of accumulation in rumen fluid. Canadian Journal of Animal Science 79: 315-319.

20. Min, B.R., Barry, T.N., Attwood, G.T. \& Mc Nabb, W.C. (2003). The effect of condensed tannins on the nutrition and health of ruminants fed fresh temperate forages: a review. Animal Feed Science and Technology, 106: 3-19.

21. Minaflinou Sacca Sidi, I.Y., Alowanou G.G., Tchétan E., Aminou M.Y., Hounzangbé-Adoté S.M., Babatoundé S. (2017). Effets de la digestion gastrique sur les propriétés anthelminthiques de Zanthoxylum zanthoxyloides (Lam.) Zepernick \& Timlerto et de Newbouldia laevis (P.Beauv.) sur Haemonchus contortus. European Scientific Journal, 13(24) : $204-216$.

22. Molan, A.L., Meagher, L.P., Spencer, P.A. \& Sivakumaran, S. (2003). Effect of flavan-3-ols on in vitro egg hatching, larval development and viability of infective larvae of Trichostrongylus colubriformis. International Journal of Parasitology, 33: 1691-1698.

23. Malecky, M., Fedele, V. \& Broudiscou, L.P. (2009). In vitro degradation by rumen bacteria of seventeen mono- and sesquiterpenes typical of winter and spring diets of goats in Basilitica rangelands (Southern Italy). Journal of the Science of Food and Agriculture, 89: 531-536.

24. Mueller-Harvey, I. (2006). Unravelling the conundrum of tannins in animal nutrition and health. Journal of the Science of Food and Agriculture, 86: 2010-2037.

25. Nwosu, C.O., Yakubu, S., Saleh, U.A. \& Abdullahi, G. (2006). In-vitro anthelmintic efficacy of crude aqueous extracts of neem (Azadirachta indica) leaf, stem and root on nematode. Animal Research International, 3: 549-552.

26. Olounladé, P.A., Hounzangbé-Adoté, M.S., Azando, E.V.B., Tamha, T.B., Brunet, S., Moulis, C., Fabre, N., Fouraste, I., Hoste, H. \& Valentin, A. (2011). Etude in vitro de l'effet des tanins de Newbouldia laevis et de Zanthoxylum zanthoxyloïdes sur la migration des larves infestantes de Haemonchus contortus. International Journal of Biological and Chemical Sciences, 5: 1414-1422.

27. Poncet-Legrand, C., Edelmann, A., Putaux, J.L., Cartalade, D., SarniManchado, P. \& Vernhet, A. (2006). Poly(L-proline) interactions with flavan-3-ols units : influence of the molecular structure and the polyphenol/protein ratio. Food Hydrocolloids, 20: 687-697.

28. Rabel, B., McGregor, R. \& Dough, P.G.C. (1994). Improved bioassay for estimation of inhibitory effects of ovine gastrointestinal mucus and anthelmintic on nematode larval migration. International Journal of Parasitology, 24: 671-676. 
29. Singh, B., Bhat, T.K. \& Sharma, O.P. (2001). Biodegradation of tannic acid in an in vitro ruminal system. Livestock Production Science, 68: 259-262.

30. Soetan, K.O., Lasisi, O.T. \& Agboluaje, A.K. (2011). Comparative assessment of in vitro anthelmintic effects of the aqueous extracts of the seeds and leaves of the African locust bean (Parkia biglobosa) on bovine nematode eggs. Journal of Cell and Animal Biology, 5: 109112.

31. Tadesse, D., Eguale, T., Giday, M. \& Mussa, A. (2009). Ovicidal and larvicidal activity of crude extracts of Maesa lanceolata and Plectranthus punctatus against Haemonchus contortus. Journal of Ethnopharmacology, 122: 240-244.

32. Tchacondo, T., Karou, S.D., Batawila, K., Agban, A., Ouro-Bang'na, K., Anani, K.T., Gbeassor, M. \& de Souza, C. (2011). Herbal remedies and their adverse effects in tem tribe traditional medicine in Togo. African Journal of Traditional, Complementary and Alternative Medicines, 8: 45-60.

33. Waterman, P.G. (1999). The tannins - An overview. In Tannins in Livestock and Human Nutrition. Proceedings of an International Workshop (ed. Brooker), Adelaide, Australia, pp. 10-13.

34. Zerbo, P., Millogo-Rasolodimby, J., Nacoulma-Ouédraogo, O.G. \& Van Damme, P. (2011). Plantes médicinales et pratiques médicales au Burkina Faso : cas des Sanan. Bois et Forêts des Tropiques, 307: 4153. 